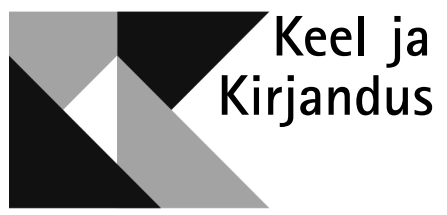

\title{
LUULETAJA ILMUMINE
}

\author{
VIIVI LUIK
}

Merel ihalen kallast

ja kaldal merd.

Pimedast surmavallast

läbi viib mõtete lend.

Tuul aina puhub ja puhub.

Aiman tas iseend

nägevat päevades, kuhu

oisi on varisend.

Artur Alliksaar

0

maenese inimese- ja luuletajakogemuse põhjal võin kinnitada: jah, luule väljendab tõepoolest seda, mis mõistuspäraselt peaks olema keele abil väljendamatu, võimatu. Jah, luules võib võimatu võimalikuks saada.

Siin peaks muidugi arvesse võtma seda, et enamik tekste, mis teesklevad luuletusi, ei ole luule, sest neis puudub see kaasahaarav jõud ja intensiivsus, ilma milleta jääb tekst surnud tekstiks. Surnuist ülestõusmise müsteeriumi ei toimu, silda inimesest inimeseni ei ehitata.

Ei piisa ka sellest, kui väljendamatu on mingis keeles ükskord täiuslikult väljendatud. Iga elavana püsiv keel vajab, et uued ja uued põlvkonnad uuesti ja uuesti leiaksid omaenese sõnad ja omaenese väljendusviisi, et nad annaksid keelele omaenda ajatunnetuse, jõu ja intensiivsuse. 
Pateetiliselt öeldes: iga keel on elav seni, kuni ikka jälle ilmub luuletaja, kes talle oma elu ohvriks toob. Kuni sellekeelse rahva hulgas leidub mõni, kelle peale suur luule silma heidab ja ta „ära” viib.

Nii nagu ta viis Eestis ära Juhan Liivi ja Juhan Viidingu. Nii nagu ta viis ära Alliksaare. Muidugimõista võib öelda, et see on ainult üks ülepaisutatud kujund ja et tegelikult viis need luuletajad ära nende eneste õnnetu elusaatus. Ka see on tõsi, kuid see on asja niinimetatud „nähtav” ja seletatav pool. Kuid teatavasti on igal asjal kaks otsa ja seal, kus on olemas nähtav ja seletatav, on kohe platsis ka nähtamatu ja seletamatu.

Alliksaare kaks lühikest rida (merel ihalen kallast / ja kaldal merd) ja nende kaudu väljendatud vastuolu on kootud iga luuletaja elumustrisse.

Luuletaja inimlik pool võitleb ja protestib luule vastu, ta ei taha olla see, kellele suur luule silma heidab, ta ei taha, et teda ära viiakse, ta tahab elada ja olla nagu igamees, nagu teised. Luuletaja on prints, kes kadestab kerjust.

Kas siis luuletaja ei tahaks teha raha ja niita muru! Ehk nagu va õnnis Tammsaare Koja-Maadami suu läbi ütles: et oleks „hea teenistus ja saaks lõunest õhtale".

Luule vaatab teatava mõistva pilkega seda võitlust pealt, ei sekku, on üle. Niigi on selge, et kelle ta kord kätte on saanud, see tema käest minema ei pääse.

Kunagi arvas Sylvia Plath, et „luuletajate lõbumaja asub surma rohtaias”, ja võib-olla on see tänini nii.

Nii kaua kui ma Paul-Eerikut tunnen (ja tunnen kaua, peaaegu kogu elu), on mind hämmastanud see, kui sügavat, kirglikku kurbust suudavad väljendada paljud tema luuletused, ja kuidas ta oma inimese-elus sellest üle püüab olla. Tema võitlus oma luuletaja-olemusega on olnud suur ja küllap see kestab kogu elu. Ta on visalt vastu hakanud, ei ole lasknud end ära viia. On peitnud end koguni Riigikogusse, paika, kust Suurel Luulel tema arust ei tule pähe teda otsida. Kuid luule teab ilma otsimatagi, kus ta peidus on.

Kui Paul-Eerikut poleks olnud, siis oleks olnud minu elu teistsugune. Ma ei oleks see, kes ma täna olen. Minule ilmus emakeel ja emakeelne luule Paul-Eeriku kujul 1963. aasta detsembris, pimedal ajal. Pimedal nii otseses kui ka kaudses tähenduses. Igaüks, kes tol ajal Eestit väljastpoolt jälgis, võis arvata, et mis seal ikka enam tulemas saab olla, sest eesti keeles kirjutavad suured luuletajad olid suuremalt jaolt kas surnud, põgenenud või vaikima sunnitud. Kuid ilmus Paul-Eerik ja lõi mängu segi, heiskas häbematult keset halli ja troostitut argipäeva kuldse lipu, mille alla koondus uus luule, uued luuletajad.

Kolmekümnendate ja neljakümnendate aastate eesti keel tõusis surnuist üles, muutus moodsaks keeleks, oma aja ja oma põlvkonna keeleks.

Muidugi olin ma ammu enne seda pimedat 1963. aasta detsembrit lugenud Liivi ja Ennot, Suitsu ja Alverit, kuid hoolimata sellest, kui hardalt või kui vaimustunult ma neid lugesin, olid Liiv, Enno ja Suits siiski juba surnud, Alver oli siiski juba vana ja kirjutas hoopis teisti, kui oli kirjutanud see uljas sõja-eelne Alver, keda ma omale kaustikusse ümber kirjutasin.

Need vanad luuletajad küll toetasid ja julgustasid mind, kuid minule oli tarvis noort ja elavat. Kedagi, kes väljendaks vanu lootusi ja vanu kurbusi 
uues sõnastuses. Kes oma olemasoluga jälle tõestaks, et suur luule on ka siin ja praegu võimalik.

Oli üks talveõhtu, ja on tänini alles, vähemalt nende mälus, kes selle õhtu kaasa tegid. Kirjanike Maja saali suurte akende ees ei olnud kardinaid, sealt ei paistnud mitte ainult pimedus, vaid ka üks iseäralik sätendus, lumevalgus. Väljas sadas tihedat, kerget ja sädelevat lund.

Saalis sees seisis Paul-Eerik, kahekümne ühe aastane, mustas ülikonnas, valges särgis, mitte sugugi Nõukogude Eesti noore luuletaja moodi. Seisis, nagu oleks ta just kuu pealt kukkunud või suure laine poolt kaldale kantud, ja luges suletud silmadega seda luuletust, kus on read: mis seal kahab iilides, pahaendeliselt hiilides. Lõikehein, oh sõber, lõikehein.

Võimalik, et selles luuletuses on mõni sõna teisiti, ma ei vaata meelega järele, sest sellisena jäi ta mulle tookord meelde, kooti elu mustrisse sisse.

Jah. 